\title{
Dopamine signaling in dorsal versus ventral striatum: the dynamic role of cholinergic interneurons
}

\author{
Sarah Threlfell, ${ }^{1,2}$ and Stephanie Jane Cragg ${ }^{1,2 *}$ \\ 1 Department of Physiology, Anatomy and Genetics, University of Oxford, Oxford, UK \\ Oxford Parkinson's Disease Centre, University of Oxford, Oxford, UK
}

\section{Edited by:}

James M. Tepper, Rutgers, The State

University of New Jersey, USA

\section{Reviewed by:}

Ingo Willuhn, University of Washington, USA

Michelle E. Ehrlich, Mount Sinai School of Medicine, USA

\section{*Correspondence:}

Stephanie Jane Cragg, Oxford

Parkinson's Disease Centre, University of Oxford, Parks Road, Oxford OX1

3PT, UK.

e-mail: stephanie.cragg@dpag.ox.ac.uk
Mesostriatal dopaminergic neurons and striatal cholinergic interneurons participate in signaling the motivational significance of environmental stimuli and regulate striatal plasticity. Dopamine (DA) and acetylcholine (ACh) have potent interactions within the striatum at multiple levels that include presynaptic regulation of neurotransmitter release and postsynaptic effects in target cells (including ACh neurons). These interactions may be highly variable given the dynamic changes in the firing activities of parent DA and ACh neurons. Here, we consider how striatal ACh released from cholinergic interneurons acting at both nicotinic and muscarinic ACh receptors powerfully modulates DA transmission. This ACh-DA interaction varies in a manner that depends on the frequency of presynaptic activation, and will thus strongly influence how DA synapses convey discrete changes in DA neuron activity that are known to signal events of motivational salience. Furthermore, this ACh modulation of DA transmission within striatum occurs via different profiles of nicotinic and muscarinic receptors in caudateputamen compared to nucleus accumbens, which may ultimately enable region-specific targeting of striatal function.

Keywords: dopamine, striatal territories, acetylcholine receptors, release probability, cholinergic interneuron

\section{INTRODUCTION}

The striatum is a large subcortical nucleus involved in motor coordination and cognition, as well as disorders such as Parkinson's disease, Tourette's syndrome, Huntington's disease, schizophrenia, and drug addiction (Wilson, 2004). The principal neurons of the striatum are the medium spiny neurons (MSNs) which constitute $\sim 90 \%$ of the striatal neuron population and form the striatal output (Bolam et al., 2000). The remaining striatal neurons are comprised of at least three types of interneuron, including the large, aspiny, tonically active cholinergic interneuron (Kawaguchi, 1993). As the input nucleus of the basal ganglia, the striatum receives, and gates massive convergent innervation via the MSNs to generate appropriate behaviors. Among this convergent innervation, striatal projection neurons receive dopaminergic inputs from the midbrain alongside excitatory inputs from both cortex and thalamus. Nigrostriatal dopaminergic afferents and corticostriatal/thalamostriatal glutamatergic afferents commonly synapse onto the same MSN dendritic spine (Moss and Bolam, 2008). Dopamine (DA) is therefore well positioned within this synaptic triad to shape striatal output.

In order to appreciate the significance of discrete activity in DA neurons to striatal function it is important to consider factors controlling the availability of DA from axon terminals in the striatum. Acetylcholine (ACh) and DA have dense overlapping axonal arborizations and a potent reciprocal relationship within the striatum. Mesostriatal DA neurons and striatal cholinergic interneurons participate in signaling the motivational significance of environmental stimuli and regulate striatal plasticity (Schultz, 1998, 2002; Calabresi et al., 2000; Partridge et al., 2002; Morris et al., 2004). Interactions between these neurotransmitters in the striatum occur at presynaptic and postsynaptic levels, through synchronous changes in their parent neuron activities and reciprocal presynaptic regulation of release (Calabresi et al., 2000; Zhou et al., 2002; Centonze et al., 2003; Pisani et al., 2003; Morris et al., 2004; Cragg, 2006). In addition, it is essential to consider that the striatum is a heterogeneous nucleus, and is organized into different (albeit overlapping) territories, anatomically, biochemically, functionally, and also neurochemically in terms of neurotransmitter interactions (Haber et al., 2000; Nakano et al., 2000; Cragg, 2003; Voorn et al., 2004; Belin et al., 2009).

A primary focus of our work is to understand how ACh regulates striatal DA neurotransmission across different striatal regions and under conditions representing the physiological repertoire of activity patterns of DA neurons. We use the real time electrochemical detection technique, fast-scan cyclic voltammetry at carbon fibermicroelectrodes to be able to explore subsecond DA transmission. This work will help us to understand how striatal DA availability varies with DA neuron activity. In this Perspective, we will draw from recent findings to summarize our current understanding of how ACh modulates DA transmission via actions at both nicotinic and muscarinic receptors. This regulation occurs in a variable manner dependent on DA neuron activity, and moreover, involves different receptor subtypes/subunits in sensorimotor- versus limbicassociated striatum.

\section{DOPAMINE AND ACETYLCHOLINE SYSTEMS IN THE STRIATUM \\ STRIATAL SUBTERRITORIES}

Collectively, the striatum participates in a wide variety of motivational, associative, and sensorimotor-related brain functions (Albin et al., 1995; Haber et al., 2000; Gerdeman et al., 2003; 
Voorn et al., 2004; Everitt and Robbins, 2005; Schultz, 2006). The striatum is a highly heterogeneous structure where the principal neurons, the MSNs, are intermingled in an irregular fashion with at least three different types of interneuron as well as a variety of inputs from cortex, thalamus, and midbrain. Within this heterogeneous structure, subterritories exist which differ according to their functional roles as well as their afferent inputs from, and projections to other nuclei. For example, dorsal striatal regions are classically associated with sensorimotor function, with glutamatergic afferents from motor cortex and dopaminergic afferents from substantia nigra pars compacta (SNc; McGeorge and Faull, 1989; Haber et al., 2000; Reep et al., 2003). Ventral striatal regions are associated with limbic function with glutamatergic afferents from prefrontal cortex, amygdala and hippocampus, and dopaminergic afferents from ventral tegmental area (VTA; Kelley and Domesick, 1982; McGeorge and Faull, 1989; Sesack et al., 1989; Brog et al., 1993; Pennartz et al., 1994; O’Donnell and Grace, 1995; Haber et al., 2000). When exploring factors which regulate striatal DA availability, it is therefore important to consider different striatal subterritories, especially when considering potential therapeutic targets for which a regional specificity of action may be ideal. And yet, while these regions are delineated in many respects, they also interact through interconnections and other crosstalk (Haber et al., 2000; Belin and Everitt, 2008; Belin et al., 2009). Therefore, factors which have distinct regulatory functions within one striatal region may also have important consequences for function in other regions.

\section{DOPAMINE AND ACETYLCHOLINE DISTRIBUTION IN STRIATUM}

A high density of dopaminergic and cholinergic terminals exists in the striatum and they are often only about $1 \mu \mathrm{m}$ apart (Descarries et al., 1997). DA inputs to the striatum arise predominantly from the "A9"-"A10" DA neurons in the midbrain. Neurons in the VTA and $\mathrm{SNc}$ project in a topographic pattern to differentially innervate the ventral striatum (nucleus accumbens, NAc) and the dorsal striatum (caudate-putamen, $\mathrm{CPu}$ ) respectively (Bjorklund and Lindvall, 1984; Gerfen et al., 1987; McFarland and Haber, 2000; Voorn et al., 2004). Mesostriatal DA neurons exhibit two broad and well-defined firing modes in vivo; single-spike firing in regular or irregular patterns $(\sim 1-10 \mathrm{~Hz})$ and burst firing of 3-5 spikes at a frequency of $\sim 15-100 \mathrm{~Hz}$ (Grace and Bunney, 1984a,b; Hyland et al., 2002), and there are also periods when DA neurons are in a hyperpolarized, quiescent state. The switch in firing mode of mesostriatal DA neurons, from low to higher firing frequencies, is thought to encode information about the prediction and receipt of reward or behaviorally salient stimuli (Schultz, 1986, 2002; Morris et al., 2004; Matsumoto and Hikosaka, 2009). Despite DA neurons forming a relatively small population of neurons, a single DA neuron projecting to the striatum forms a very dense arbor, occupying up to $5.7 \%$ of the volume of the striatum, with a high density of axonal varicosities forming a synapse approximately every 10-20 $\mu^{3}$ (Descarries et al., 1996; Arbuthnott and Wickens, 2007; Matsuda et al., 2009; Moss and Bolam, 2010). Furthermore, an individual DA neuron is thought to make several hundred thousand synapses - at least an order of magnitude higher than most other CNS neurons (Matsuda et al., 2009). Although DA neurons make a huge number of structurally defined synapses, DA receptors and uptake transporters exist extrasynaptically (Nirenberg et al., 1996, 1997; Pickel, 2000) and DA is able to spillover from the synapse to participate in extrasynaptic or "volume" transmission (Fuxe and Agnati, 1991; Garris et al., 1994; Gonon, 1997; Cragg and Rice, 2004; Rice and Cragg, 2008). DA is therefore extremely well positioned to modulate striatal function: DA synapses are situated on the necks of spines of MSNs adjacent to corticostriatal or thalamostriatal glutamatergic inputs (Freund et al., 1984; Smith and Bolam, 1990; Groves et al., 1994; Moss and Bolam, 2008). DA receptors are present throughout the striatum, with D1-like receptors on striatonigral MSNs (Hersch et al., 1995; Matamales et al., 2009) and D2-like receptors on striatopallidal MSNs, cholinergic interneurons as well as DA axons (Sesack et al., 1994; Alcantara et al., 2003; Matamales et al., 2009).

In the striatum, cholinergic innervation arises solely from cholinergic interneurons (Woolf, 1991; Contant et al., 1996; Calabresi et al., 2000), which despite representing only $1-2 \%$ of all striatal neurons, provide an extensive axonal arborization throughout the striatum in a manner similar to dopaminergic axons. Quantitative electron microscopy studies indicate approximately $2 \times 10^{8} \mathrm{ACh}$ varicosities $/ \mathrm{mm}^{3}$ in the striatum, and each striatal cholinergic interneuron has 500,000 axon varicosities. Similar to dopaminergic axon terminals, a $10-\mu \mathrm{m}$-radius sphere of striatal neuropil contains about 400 cholinergic axon terminals (Contant et al., 1996; Descarries and Mechawar, 2000). These cholinergic interneurons are spontaneously active in the striatum (Bennett and Wilson, 1999; Zhou et al., 2001, 2003). Similar to dopaminergic neurons, cholinergic interneurons are also critically involved in signaling learning associated with events of unexpected high salience (Calabresi et al., 2000; Schultz, 2002; Berridge and Robinson, 2003; Centonze et al., 2003; Wickens et al., 2003; Wise, 2004). Whilst DA neurons signal these events by switching from low to higher frequency, burst firing modes (Schultz, 1986, 2002; Morris et al., 2004; Matsumoto and Hikosaka, 2009), cholinergic interneurons respond simultaneously with a pause in firing which can also be flanked by a preceding and succeeding brief high frequency firing in a "burst-pause-burst" pattern (Morris et al., 2004; Joshua et al., 2008). The coincident timing of activity changes in DA and ACh neurons associated with events of unexpected salience highlights the synchronous interaction between these transmitters in the striatum.

Both DA and ACh are able to participate in extrasynaptic signaling (i.e., volume transmission; Descarries et al., 1996, 1997; Zoli et al., 1998), but the close proximity of striatal dopaminergic and cholinergic terminals ensures interactions between the dopaminergic and cholinergic systems. Indeed, the co-operative interactions of the dopaminergic and cholinergic systems are very important for the proper functioning of the striatum (Calabresi et al., 2000; Centonze et al., 2003; Rice and Cragg, 2004; Zhang and Sulzer, 2004; Cragg et al., 2005). There is a longstanding hypothesis of an antagonistic balance between DA and ACh in normal striatal function (Calabresi et al., 2000; Zhou et al., 2002; Centonze et al., 2003; Pisani et al., 2003). This hypothesis arose from studies which found that both DA replacement treatments and anti-cholinergic treatments were able to alleviate the debilitating motor symptoms of Parkinson's disease (Barbeau, 1962; Pisani et al., 2003), and at the postsynaptic level, DA and ACh can have opposing effects on the excitability of striatal output neurons and on corticostriatal plasticity (Calabresi et al., 2000, 2007; Centonze et al., 2003; 
Pisani et al., 2003; Morris et al., 2004). Their interactions in situ may however be co-operative (Morris et al., 2004; Cragg, 2006), since the direction of physiological changes in activities of DA and ACh neurons during behavior is opposite.

Striatal ACh acts at two classes of cholinergic receptors, nicotinic acetylcholine receptors (nAChRs), and muscarinic acetylcholine receptors ( $\mathrm{mAChRs).} \mathrm{Nicotinic} \mathrm{receptors} \mathrm{are} \mathrm{ligand-gated}$ ion channels composed of five subunits arranged symmetrically around a central pore. Muscarinic receptors are seven transmembrane domain, G-protein-coupled receptors. ACh via actions at both mAChRs and nAChRs is able to powerfully regulate striatal DA availability in a manner which differs according to the striatal subregion and DA neuron activity. In addition, the subtypes of both mAChRs and nAChRs responsible differ between dorsal and ventral striatal territories.

\section{FREOUENCY-DEPENDENT REGULATION OF DOPAMINE RELEASE PROBABILITY BY PRESYNAPTIC NICOTINIC RECEPTORS (nAChRs)}

Striatal DA release may not correlate directly with the activity of DA neurons in midbrain due to mechanisms that may include use-dependent changes or "plasticity" in DA release probability (Chergui et al., 1994; Cragg, 2003; Montague et al., 2004) as seen at other CNS synapses. Within the striatum, DA release probability following a single action potential is relatively high, with subsequent short-term depression limiting further release by subsequent action potentials within a burst of action potentials (Schmitz et al., 2002; Cragg, 2003).
Ligands for nAChRs have long been known to have a powerful control over striatal DA release (Di Chiara and Imperato, 1988; Dajas-Bailador and Wonnacott, 2004). However, we now appreciate that the control of DA release probability by ACh and presynaptic $\mathrm{nAChRs}$ is dynamic and complex depending on the activity of DA neurons and multiple nAChR subunits (Zhou et al., 2001; Rice and Cragg, 2004; Zhang and Sulzer, 2004; Exley et al., 2008; Drenan et al., 2010; Threlfell et al., 2010). Typically, striatal DA release is associated with a use-dependent, short-term depression of release probability at short inter-pulse intervals (Abeliovich et al., 2000; Cragg, 2003; Montague et al., 2004). Studies using real time electrochemical detection of DA in striatal slices indicate that $\mathrm{ACh}$ released from tonically active cholinergic interneurons (Bennett and Wilson, 1999; Zhou et al., 2001, 2003) acts at $\beta 2$-subunit-containing $(\beta 2 *)$-nAChRs on striatal DA axons contributing to the high probability of DA release evoked by a single pulse (Zhou et al., 2001; Rice and Cragg, 2004). Reducing ACh actions at nAChRs by application of $\mathrm{nAChR}$ antagonists, or by desensitization of $\mathrm{nAChRs}$ using nicotine, reduces initial DA release probability and subsequently relieves short-term depression (Figure 1; Rice and Cragg, 2004; Zhang and Sulzer, 2004). ACh therefore contributes to the initial probability that DA is released, and in turn, the subsequent shortterm depression of DA release.

One of the key consequences of ACh activation of nAChRs on dopaminergic axons is a limit placed on how subsequent action potentials in a train, or burst, can evoke further DA release. In other words, ACh action at nAChRs promotes how DA axons release in response to single or low frequency action potentials, but at the
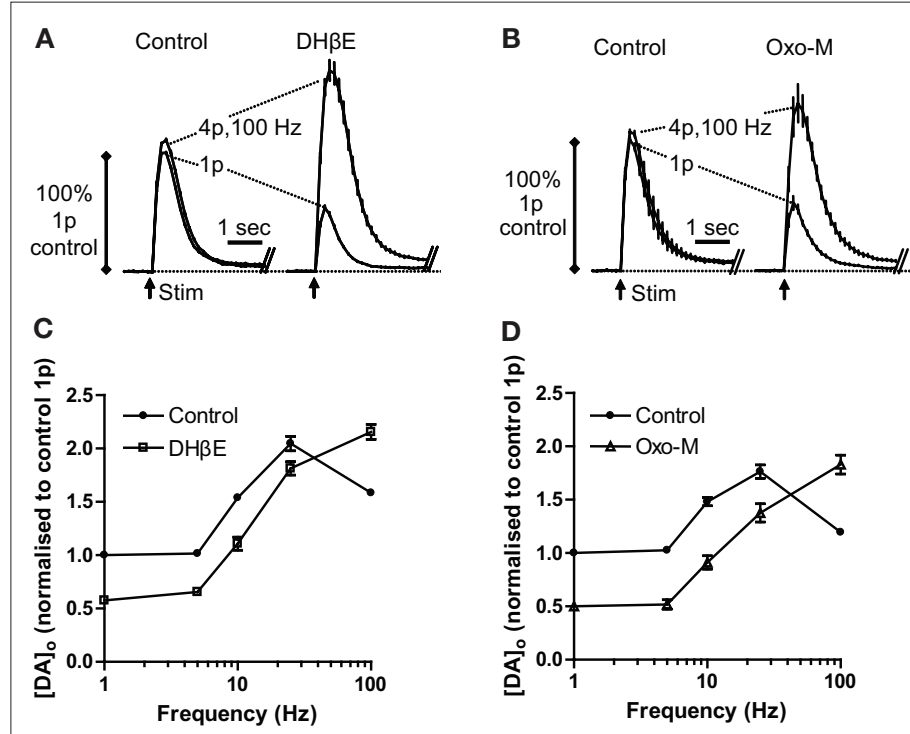

FIGURE 1 | Nicotinic (nAChRs) and muscarinic (mAChRs) receptors modify frequency-dependence of dopamine release. $(A, B)$ Profiles of mean extracellular concentration of dopamine $[D A]_{0} \pm$ SEM versus time in NAc after stimuli (arrows) of either a single pulse (1p) or a high frequency burst $(4 \mathrm{p} / 100 \mathrm{~Hz})$ in control or drug conditions ( $\mathrm{DH} \beta \mathrm{E}, 1 \mu \mathrm{M}$; Oxo-M, $10 \mu \mathrm{M})$. Data are normalized to peak $[D A]_{0}$ released by $1 p$ in controls. Either $\beta 2 *-n A C h R$ antagonist (DH $\beta E$ ) or $\mathrm{mAChR}$ agonist (Oxo-M) reduce release by a single pulse and enhance release by a burst thereby increasing the contrast between dopamine released by burst and non-burst activity. (C,D) Mean peak $[D A]_{0} \pm$ SEM versus frequency during

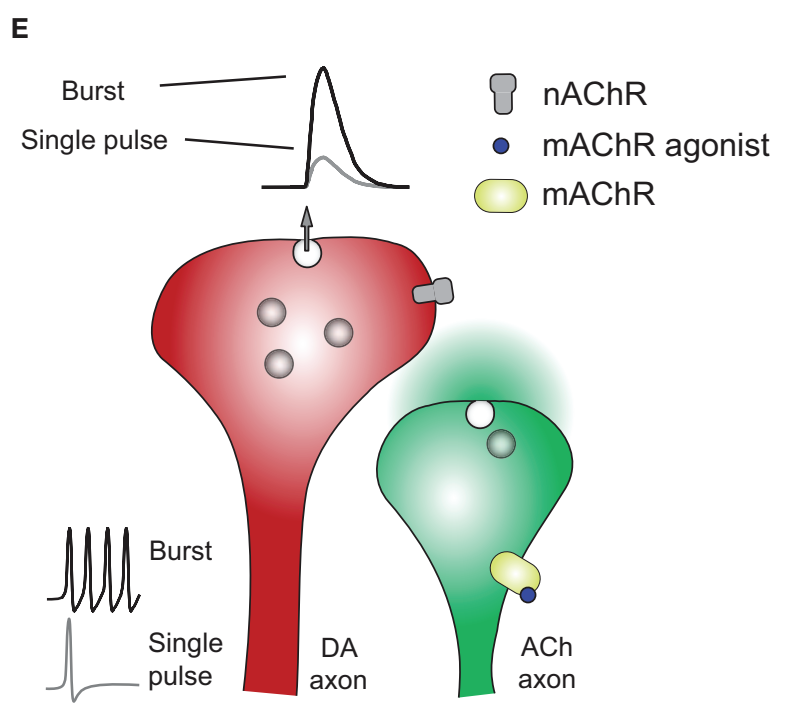

four pulse trains $(1-100 \mathrm{~Hz}$ ) in control (filled circles) or DHßE (squares) or Oxo-M (triangles) normalized to [DA] $]_{0}$ released by a single pulse in control conditions. Either blockade of $\mathrm{nAChRs}$ with $\mathrm{DH} \beta \mathrm{E}$, or activation of $\mathrm{mAChRs}$ with Oxo-M results in increased frequency-dependence of dopamine release as described previously (see Rice and Cragg, 2004; Exley et al., 2008; Threlfell et al., 2010). (E) Schematic illustrating the frequency-dependence of dopamine release during deactivation of $n A C h R s$ as a result of either blockade/desensitization of presynaptic nAChRs on dopamine terminals or activation of mAChRs on cholinergic interneurons. 
expense of greater release during high frequency action potentials, e.g., in a burst. Thus, nAChRs limit how well striatal DA release correlates with the frequency of activity of DA neurons in midbrain; nAChR activity promotes a "low frequency pass" filter. Conversely, when nAChRs are turned off, and short-term depression of DA release probability is relieved, striatal DA release becomes highly sensitive to the frequency of activity of DA neurons. It can be viewed that nAChR blockade suppresses initial DA release but permits a "high frequency pass" filter as seen at many CNS synapses (Rice and Cragg, 2004; Cragg, 2006). Consequently, reduced nAChR activity can (a) augment DA release following bursts of DA neuron activity $(>20 \mathrm{~Hz})$ such as those that accompany presentation of unexpected reward or conditioned salient stimuli (Mirenowicz and Schultz, 1996; Hyland et al., 2002) and (b) reduce DA release during low DA neuron activity such as that seen following omission of a expected reward (Tobler et al., 2003). This enhanced sensitivity of DA release to activity in DA neurons during low nAChR activity may occur during pauses in activity in ACh interneurons.

This ability of ACh via nAChRs to regulate DA availability in a manner that is dependent on frequency of DA neurons suggests that changes in ACh interneuron activity, e.g., pauses, will have key consequences on DA signaling when DA neurons concurrently switch from firing at low frequencies to bursts of high frequency activity, such as during events of high salience. A pause in the nAChR filtering mechanism will increase the contrast in DA signaling during different modes of activity of DA neurons and ultimately enhance DA function at the level of the MSN by modulating DA action at D1 or D2 receptors on discrete MSN populations as well as other DA receptor-expressing interneurons/axons.

\section{nAChR SUBUNITS ON STRIATAL DOPAMINE AXONS}

Dopamine neurons express a range of $\mathrm{nAChR}$ subunits, and several different stoichiometric configurations are proposed to exist in DA axons and regulate striatal DA transmission. Currently, 14 mammalian nAChR subunits $\alpha 1-\alpha 10$ and $\beta 1-\beta 4$ have been identified. These subunits are organized into subfamilies I-IV, according to gene sequence and structure (Corringer et al., 2000; Le Novere et al., 2002). To date, only nine nAChR subunits from subfamilies II ( $\alpha 7)$ and III $(\alpha 2-\alpha 6, \beta 2-\beta 4)$ have been identified in mammalian brain (Corringer et al., 2000; Le Novere et al., 2002). These subunits can form homomeric pentamers (all of one type of subunit, e.g., $\alpha 7$ ) or heteromeric pentamers, consisting of combinations of various $\alpha$ - and $\beta$-type subunits. In rodents, DA neurons in VTA and SNc express mRNAs for the nAChR subunits $\alpha 4, \alpha 5, \alpha 6, \beta 2$, and $\beta 3$, as well as lower levels of $\alpha 3, \alpha 7$, and $\beta 4$ (Azam et al., 2002). This diversity of subunit expression has the potential to give rise to multiple types of pentameric receptors in somatodendritic and axon terminal regions of DA neurons with a corresponding multitude of potential functions.

Differences in the nAChR subunits present in axon terminals versus somatodendritic regions of DA neurons exist. Whereas $\alpha 7$ and $\beta 4$-subunits are present in VTA and SNc, they are not present in DA axon terminals in striatum (Champtiaux et al., 2003; Quik et al., 2005). Furthermore, despite existing in the primate striatum, there is no $\alpha 3$-subunit in rodent striatum (Wonnacott et al., 2000; Zoli et al., 2002; Champtiaux et al., 2003; Gotti et al., 2005; Quik et al., 2005). The $\alpha 4, \alpha 5, \alpha 6, \beta 2$, and $\beta 3$ subunits are however found at high density in DA axon terminals in rodent striatum, where they can assemble as functional heteromeric nicotinic receptors. As heteromeric receptors, nicotinic subunits arrange to form two $\alpha / \beta$ pairs, and a fifth subunit, $\alpha$ or $\beta$. The boundary of each $\alpha / \beta$ pair is one of two ACh-binding sites at each nAChR (Gotti and Clementi, 2004) which must be occupied for the receptor to function. In striatal DA axons, the two $\alpha / \beta$ pairs are the $\alpha 4 / \beta 2$ and/ or $\alpha 6 / \beta 2$ and/or $\alpha 4 / \beta 4$ (Luetje, 2004; Salminen et al., 2004; Quik et al., 2005). The fifth subunit in the nAChR pentamer may consist of any other subunit, including $\alpha 5$ or $\beta 3$.

All nAChRs on striatal DA axon terminals are thought to contain the $\beta 2$ subunit (Champtiaux et al., 2003; Salminen et al., $2004)$. Deduction of the other subunits present within these $\beta 2 \%$ nAChRs has been aided by use of a selective $\alpha 6-/ \alpha 3 *$-nAChR antagonist $\alpha$-conotoxin MII ( $\alpha$-CtxMII; Cartier et al., 1996; Whiteaker et al., 2000; McIntosh et al., 2004). The majority of striatal nAChRs located on DA terminals can therefore be separated into two groups according to their sensitivity to $\alpha$-CtxMII. Studies using $\alpha$-CtxMII to determine which nAChR subunits are responsible for nicotine-evoked striatal DA release from synaptosomes have revealed that up to $60 \%$ of nicotine-evoked DA is not prevented by $\alpha$-CtxMII and therefore results from non- $\alpha 6 *$ nAChRs (Kulak et al., 1997; Kaiser et al., 1998; Salminen et al., 2007). Therefore both $\alpha 6 *$-nAChRs (comprising $\alpha 6 \alpha 4 \beta 2 \beta 3$ and $\alpha 6 / \beta 2 *$ ) and non- $\alpha 6 *$-nAChRs (comprising $\alpha 4 \beta 2$ and $\alpha 4 \alpha 5 \beta 2$ ) exist on striatal DA axons (Zoli et al., 2002; Champtiaux et al., 2003; Salminen et al., 2004; Quik et al., 2005; Exley and Cragg, 2008; Gotti et al., 2009; Jennings et al., 2009). However as emerging data is beginning to indicate, expression does not necessarily indicate function.

\section{nAChR SUBUNITS RESPONSIBLE FOR REGULATION OF STRIATAL DOPAMINE TRANSMISSION IN DORSAL VERSUS VENTRAL STRIATUM}

Previous studies identifying the subunits responsible for nicotinic regulation of striatal DA release from synaptosomes have typically not differentiated between striatal subterritories. It is important to distinguish factors (such as $\mathrm{nAChR}$ subunits) regulating $\mathrm{DA}$ availability across different striatal subregions due to different the behaviors associated with distinct striatal subterritories. For example, DA neurons innervating more dorsal striatal regions are those most vulnerable in Parkinson's disease, therefore understanding mechanisms regulating availability of DA within such territories will help to unveil future therapeutic targets/neuroprotective strategies in such diseases.

Recent work from our own lab using the $\alpha 6$-selective nAChR antagonist $\alpha$-CtxMII has revealed that $\alpha 6 *$-nAChRs dominate activity-dependent regulation of DA transmission in ventral striatum, whereas in dorsal striatum $\alpha 6 *-n A C h R s$ play a minor role (Exley and Cragg, 2008; Exley et al., 2008). Due to a lack of other subunit-specific pharmacological nAChR ligands, further delineation of the nAChR subunits necessary for activity-dependent regulation of DA transmission requires the use of subunit-null and transgenic mice expressing mutant $\mathrm{nAChR}$ subunits. A recent study using mice expressing a non-native hypersensitive $\alpha 6$ subunit $\left(\alpha 6^{\prime}\right)$ revealed activity-dependent DA release in central CPu in the absence of any $\mathrm{nAChR}$ ligand. This activity-dependence was absent in $\alpha 6^{\prime}$ mice lacking $\alpha 4$ subunits ( $\alpha 6^{\prime} \alpha 4 \mathrm{KO}$ ), which the authors 
suggested might indicate a role for $\alpha 6 \alpha 4 \beta 2 *$ nAChRs in regulation of DA release in the central CPu region (Drenan et al., 2010). However, this role remains to be established for native $\alpha 6$ subunits in $\mathrm{CPu}$, and moreover, unpublished data from our own lab in knockout mice continues to suggest that $\alpha 6 \beta 2 *$-nAChRs in dorsal striatum play only a limited role compared to $\alpha 4 \beta 2 *$-nAChRs, whereas $\alpha 4 \alpha 6 \beta 2 *$-nAChRs may dominate $\beta 2 *$-nAChR function in NAc (Exley et al., 2011).

\section{FREQUENCY-DEPENDENT REGULATION OF DOPAMINE RELEASE PROBABILITY BY MUSCARINIC AUTORECEPTORS (mAChRs) ON CHOLINERGIC INTERNEURONS}

Like nAChRs, muscarinic receptors (mAChRs) are also able to regulate striatal DA availability. Until recently, data within the literature was conflicting, with some reports suggesting that mAChRs enhance DA release (Lehmann and Langer, 1982; Raiteri et al., 1984; Schoffelmeer et al., 1986; Xu et al., 1989; De Klippel et al., 1993; Zhang et al., 2002b; Grilli et al., 2008), and others reporting the opposite (Schoffelmeer et al., 1986; Kemel et al., 1989; Xu et al., 1989; De Klippel et al., 1993; Kudernatsch and Sutor, 1994; Zhang et al., 2002b; Tzavara et al., 2004). Recent data from our lab has revealed that $\mathrm{mAChRs}$ can in fact regulate DA bidirectionally depending on activity of DA neurons (Threlfell et al., 2010). This activity-dependent regulation of DA by $\mathrm{mAChRs}$ is reminiscent of that shown by nicotinic receptors (Rice and Cragg, 2004; Zhang and Sulzer, 2004; Exley et al., 2008).

Activation of striatal mAChRs inhibits DA release by single pulses or low frequencies of presynaptic activity, but enhances the sensitivity of DA release to frequency, increasing DA released by higher frequencies (Threlfell et al., 2010). Thus, either activation of mAChRs, or inhibition/desensitization of nAChRs enhances the sensitivity of DA release to frequency, and as such restores release to exhibit classical, dynamic probability of neurotransmitter release as seen at other synapses (Thomson, 2000a,b). However, unlike for striatal nAChRs, there is no anatomical evidence for the presence of striatal mAChRs on dopaminergic axon terminals to influence DA release directly (Jones et al., 2001; Zhang et al., 2002b; Zhou et al., 2003). Many other striatal neurons by contrast, express and are regulated by $\mathrm{mAChRs,} \mathrm{including} \mathrm{striatal} \mathrm{cholinergic} \mathrm{interneu-}$ rons (Bernard et al., 1992, 1998; Yan and Surmeier, 1996; Alcantara et al., 2001; Bonsi et al., 2008), GABAergic interneurons (Koos and Tepper, 2002), MSNs (Weiner et al., 1990; Levey et al., 1991; Calabresi et al., 2000; Yan et al., 2001), and glutamatergic afferents (Sugita et al., 1991; Calabresi et al., 2000; Pakhotin and Bracci, 2007). Previous studies have identified regulation of DA release by mAChRs on a variety of striatal neurons/inputs. For example, $\mathrm{mAChR}$ regulation of $\mathrm{GABA}$ acting at $\mathrm{GABA}_{\mathrm{A}}$ receptors has been implicated in the control of DA in protocols using high $\left[\mathrm{K}^{+}\right]$to evoke [ $\left.{ }^{3} \mathrm{H}\right]$ DA release (Zhang et al., 2002b), but the mAChR modulation of dynamic DA release probability that we have described during discrete electrical stimuli persists in the presence of synaptic blockers for GABA/glutamate (Threlfell et al., 2010). Rather, this dynamic regulation of striatal DA by $\mathrm{mAChRs}$ requires cholinergic tone at nAChRs on DA axons, since blockade of ACh input from cholinergic interneurons to $\mathrm{nAChRs}$ precludes effects of $\mathrm{mAChR}$ activation and vice versa. Striatal cholinergic interneurons express somatodendritic and axonal mAChRs (Bernard et al., 1992, 1998;
Alcantara et al., 2001; Zhang et al., 2002a), which are autoreceptors. When these autoreceptors are activated cholinergic interneurons become silenced and ACh release is inhibited (via inhibition of $\mathrm{Ca}_{\mathrm{v}}$ 2-type $\mathrm{Ca}^{2+}$ conductances and/or $\mathrm{K}_{\mathrm{v}}^{+}$channel opening; Raiteri et al., 1984; Schoffelmeer et al., 1986; Yan and Surmeier, 1996; Calabresi et al., 1998, 2000; Zhang et al., 2002a; Zhou et al., 2003; Ding et al., 2006; Bonsi et al., 2008). The reduction in ACh release following mAChR autoreceptor activation consequently deactivates $n A C h R s$ on dopaminergic axons, and in turn, increases the sensitivity of DA release to presynaptic depolarization frequency as seen following inhibition/desensitization of nicotinic receptors (see Figure 1).

These data revise our understanding of striatal mAChR-DA interactions in several ways. Firstly, striatal mAChRs offer variable, bidirectional control of DA release probability depending on presynaptic activity. This reconciles previous contradictory findings since striatal mAChRs do not simply suppress or enhance DA release but can do both depending on the frequency of depolarization. Secondly, this variable mAChR control of DA release is not via multiple striatal neuron types but via the control of ACh release from striatal cholinergic interneurons. These mAChRs, by modifying ACh release, powerfully gate the $\mathrm{nAChR}$ regulation of $\mathrm{DA}$ release. Finally, we also show important differences in the mAChR subtypes regulating DA (and cholinergic interneurons) in sensorimotor- versus limbic-associated striatum.

\section{mAChR SUBTYPES AND LOCATIONS WITHIN STRIATUM}

Five different types of $\mathrm{mAChRs}$ exist in the striatum, $\mathrm{M}_{1}-\mathrm{M}_{5}$, these G-protein-coupled mAChRs are present throughout the striatum on a variety of neurons and axon terminals. Like DA receptors, these $\mathrm{mAChRs}$ are commonly divided into two families, $\mathrm{M}_{1}$-like $\left(\mathrm{M}_{1}, \mathrm{M}_{3}\right.$, and $\left.\mathrm{M}_{5}\right)$ and $\mathrm{M}_{2}$-like $\left(\mathrm{M}_{2}\right.$ and $\left.\mathrm{M}_{4}\right)$ according to the G-protein the receptor is coupled to. $M_{1}$-like receptors are coupled to the $G_{s}$ class of $G_{\alpha}$ proteins, whereas $M_{2}$-like receptors are coupled to $G_{i}$ proteins, thereby modulating different intracellular signaling pathways. The muscarinic receptor subtypes $M_{1}, M_{2}$, and $M_{4}$, are the dominant striatal subtypes (Zhang et al., 2002b; Zhou et al., 2003). There is now considerable evidence that discrete expression and function of $M_{1}, M_{2}$, and $M_{4}$ receptors can be partitioned to different striatal neurons and neurotransmitter interactions. For example, MSNs express primarily $M_{1}$ and $M_{4}$, with $M_{4}$ receptors dominant on striatonigral MSNs with very low or undetectable levels of $M_{2}, M_{3}$, and $\mathrm{M}_{5}$ (Weiner et al., 1990; Levey et al., 1991; Santiago and Potter, 2001; Yan et al., 2001; Shen et al., 2005; Wang et al., 2006). Striatal cholinergic interneurons by contrast have dominant expression and function of $\mathrm{M}_{2}$ and $\mathrm{M}_{4} \mathrm{mAChRs}$ (Yan and Surmeier, 1996; Bernard et al., 1998; Alcantara et al., 2001; Ding et al., 2006). $\mathrm{M}_{5}$ receptors are expressed by midbrain DA neurons where they mediate midbrain actions of ACh inputs (Forster et al., 2002; Lester et al., 2010), but current anatomical evidence does not suggest that they are transported to DA axon terminals in the striatum (Weiner et al., 1990).

\section{DIFFERENT mAChR SUBTYPES ARE RESPONSIBLE FOR REGULATION OF STRIATAL DOPAMINE IN DORSAL VERSUS VENTRAL STRIATUM}

The mAChRs regulating striatal DA release differ between dorsal and ventral striatal subterritories. Due to the poor pharmacological selectivity of drug ligands for specific distinct muscarinic receptor 
subtypes (ligands are subtype-preferring but not selective), we have made use of transgenic mice lacking individual mAChR subtypes (Wess et al., 2003) to study the receptor subtypes that are responsible for regulation of DA in specific striatal subregions. The use of knockout mice as tools to study normal receptor function is not always free from caveats as such mice can often display significant compensation for gene deletions. However, there appears to be little or no compensation in remaining $\mathrm{mAChRs}$ for the subtypespecific null mice used here (Gomeza et al., 1999a,b). Given that cholinergic interneurons are responsible for a powerful modulation of striatal DA, we studied mice lacking the receptors those interneurons usually express as autoreceptors: $\mathrm{M}_{2}-$ and $\mathrm{M}_{4}-\mathrm{mAChRs}$. We also explored $\mathrm{mAChR}$ control of DA release in $\mathrm{M}_{5}-\mathrm{mAChR}$ null mice. Although there is a lack of anatomical evidence that these receptors can be found on striatal DA axons, midbrain DA neurons express $M_{5}$ receptors for midbrain ACh function (Forster et al., 2002; Lester et al. 2010) and there is some limited evidence that striatal $\mathrm{M}_{5}$ Rs might regulate DA transmission (Zhang et al., 2002b; Bendor et al., 2010).

In dorsal striatum, a region classically associated with motor function, both $\mathrm{M}_{2}$ - and $\mathrm{M}_{4}-\mathrm{mAChRs}$ are necessary for muscarinic regulation of DA release. Deletion of either $\mathrm{M}_{2}-$ or $\mathrm{M}_{4}-\mathrm{mAChRs}$ prevents muscarinic receptor modulation of DA (Threlfell et al., 2010). By contrast in more limbic striatal regions, in the NAc core or shell, only the $\mathrm{M}_{4}-\mathrm{mAChR}$ is necessary for muscarinic receptor control (Threlfell et al., 2010). Deletion of $\mathrm{M}_{2}$-mAChRs in the NAc core or shell does not prevent muscarinic control of DA; only deletion of the $\mathrm{M}_{4}-\mathrm{mAChR}$ eliminates muscarinic control. In both dorsal striatum and NAc, elimination of the $\mathrm{M}_{5}-\mathrm{mAChR}$ has no effect on the activity-dependent regulation of DA by muscarinic receptors therefore they do not participate in activity-dependent regulation of DA by mAChR agonists. However, muscarinic-mediated suppression of DA release following single pulse stimulation in mice lacking the $\mathrm{M}_{5} \mathrm{R}$ does appear to be more pronounced in both dorsal and ventral striatum suggesting that if presynaptic $M_{5}$ Rs do exist on a subset of DA terminals, they function to enhance DA release, as suggested by others (Zhang et al., 2002b; Bendor et al., 2010).

At present, it is unclear why such differences in $\mathrm{mAChR}$ control of DA release by $\mathrm{M}_{2} / \mathrm{M}_{4} \mathrm{mAChRs}$ would exist between dorsal and ventral striatum. It is currently unknown whether these differences are attributable to different expression/role of $\mathrm{M}_{4} \mathrm{Rs}$ versus $\mathrm{M}_{2} \mathrm{Rs}$ in cholinergic interneurons that innervate each territory, or a different basal ACh tone at nAChRs, or whether there are other intrinsic regional differences in cholinergic interneurons including compensatory adaptations that can accommodate loss of $\mathrm{M}_{2} \mathrm{Rs}$ in NAc but not in dorsal striatum. There is no comparative study of expression/function of mAChRs in regulation of cholinergic activity in dorsal versus ventral striatum and no evidence for a difference in the levels of ACh reaching nAChRs (Exley et al., 2008). There are however, reports that mAChRs are found at higher levels in ventral than dorsal striatum in rats (Tayebati et al., 2004) and that cholinergic interneurons in limbic/prefrontal versus sensorimotor territories can be differentiated by different expression levels of other types of receptors ( $\mu$-opioid; Jabourian et al., 2005). Thus, distinct muscarinic mechanisms/receptors in subpopulations of cholinergic interneurons may explain the differing $\mathrm{mAChR}$ control of DA release in dorsal striatum and NAc. These regional differences in $\mathrm{M}_{2} / \mathrm{M}_{4}$ function could ultimately be exploited for discrete modulation of DA/ACh. For example, $\mathrm{ACh} /$ DA function might be modified selectively in NAc by activation of $\mathrm{M}_{4} \mathrm{Rs}$, and in dorsal striatum by $\mathrm{M}_{2} \mathrm{R}$ inhibition. It is possible that regional differences may exist due to differential intracellular coupling of $\mathrm{M}_{2}-$ and $\mathrm{M}_{4}-\mathrm{mAChRs}$ on cholinergic interneurons in different striatal regions, or perhaps differential expression of $\mathrm{M}_{2}-$ and $\mathrm{M}_{4}-\mathrm{mAChRs}$ on cholinergic interneurons in these two regions. Further electrophysiological characterization of cholinergic interneurons in mice lacking $\mathrm{M}_{2}$ - or $\mathrm{M}_{4}-\mathrm{mAChRs}$ may shed light on potential differences between dorsal and ventral striatum, and is currently underway.

\section{SUMMARY AND PERSPECTIVE}

Striatal nAChRs and mAChRs powerfully modulate DA transmission in a manner that varies with presynaptic activity in DA neurons. This regulation can strongly influence how DA synapses transmit discrete bursts in neuronal activity that signal events of motivational salience, and in turn will influence all DA-dependent functions of the striatum. Intriguingly, cholinergic modulation of DA transmission within striatum is via regionally specific portfolios of nicotinic (Exley et al., 2008, 2011) and muscarinic (Threlfell et al., 2010) receptors (Figure 2), which may ultimately enable region-specific targeting of striatal function. For example, $\mathrm{ACh} /$ DA function within striatum could be modified selectively in NAc by activation of $\mathrm{M}_{4} \mathrm{Rs}$, and in dorsal striatum by $\mathrm{M}_{2} \mathrm{R}$ inhibition. A specific nAChR such as the $\alpha 4 \alpha 6 \beta 2 *-n A C h R$ in NAc might be a target to exploit in the treatment of nicotine addiction. There are longstanding notions that there is a postsynaptic antagonistic balance between striatal ACh and DA and that antimuscarinic therapies are useful in diseases like Parkinson's and dystonia (e.g., see Pisani et al., 2007). The suppression of striatal ACh release by $\mathrm{M}_{2} / \mathrm{M}_{4}$ autoreceptors together with the effects of $\mathrm{M}_{2} / \mathrm{M}_{4}$ receptor activation on DA transmission reviewed here give support to the notion that enhancers of muscarinic $M_{2} / M_{4}$ receptor function might be a useful therapy in such disorders (Pisani et al., 2007). More generally, these data also highlight that regulation of DA neurotransmission by a given neuromodulator is not fixed, or unidirectional; it can be variable and bidirectional in an activity-dependent manner, a principle which may apply equally to other neuromodulators and neurotransmitters.

With increasing availability of new molecular biological tools facilitating neuron-specific elimination/expression of proteins, we are in a better position than ever to advance our appreciation of how receptors in the basal ganglia are able to regulate striatal function. The advancing field of optogenetics which exploits genetics to incorporate light activated ion channels (rhodopsins) into genetically defined populations of neurons to allow activation or inhibition of these neurons with high temporal precision, will undoubtedly facilitate future studies of the complex interplay of a multitude of neurotransmitters and neuromodulators within the highly heterogenous striatum. When considering how striatal output governs different behaviors, it is imperative to assess the role played by interactions between many striatal neurotransmitters and neuromodulators and the ACh-DA interaction is one powerful interaction that should be given appropriate consideration. 


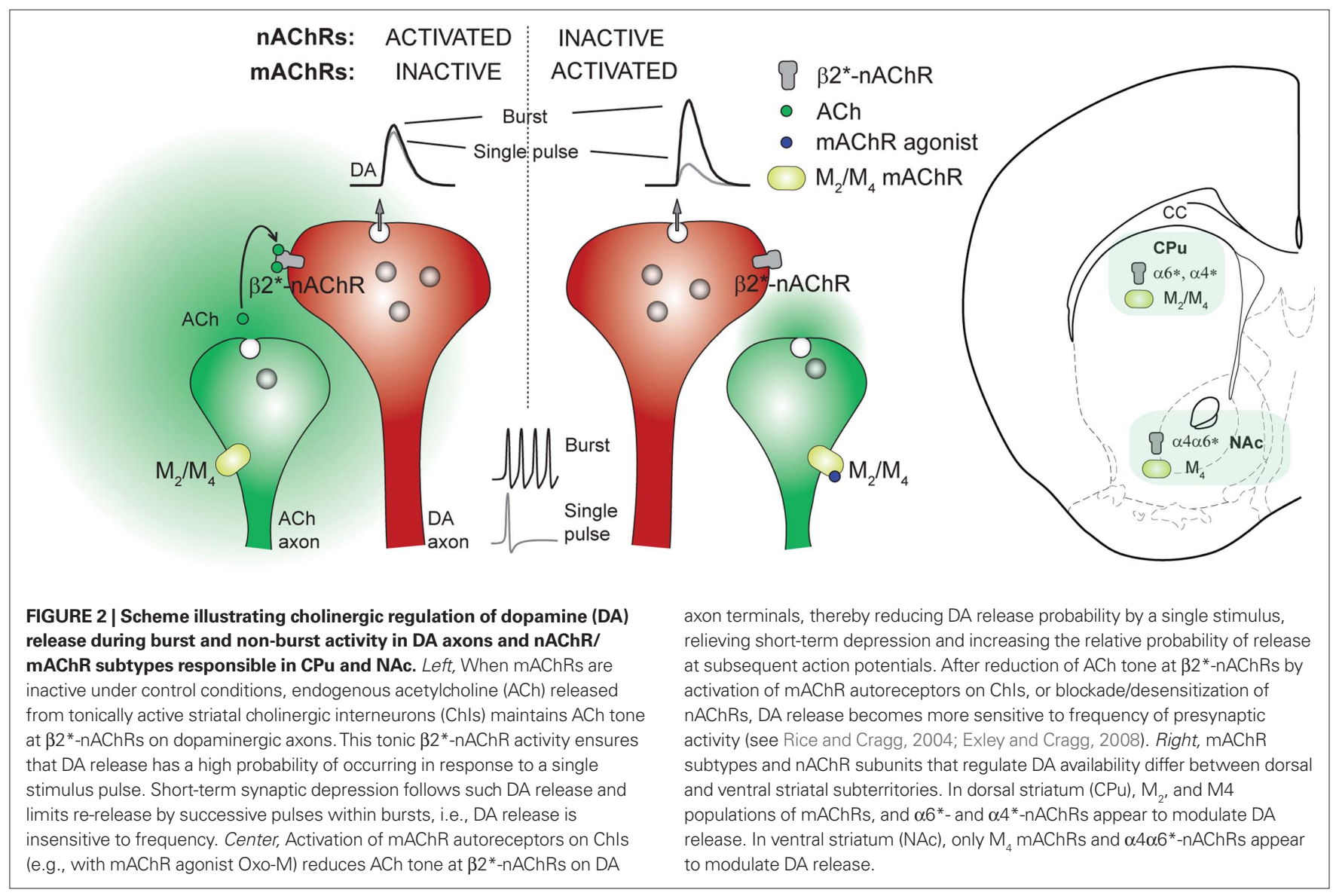

\section{REFERENCES}

Abeliovich, A., Schmitz, Y., Farinas, I., Choi-Lundberg, D., Ho, W. H., Castillo, P. E., Shinsky, N., Verdugo, J. M.,Armanini, M., Ryan, A., Hynes, M., Phillips, H., Sulzer, D., and Rosenthal, A. (2000). Mice lacking alpha-synuclein display functional deficits in the nigrostriatal dopamine system. Neuron 25, 239-252.

Albin, R. L., Young, A. B., and Penney, J. B. (1995). The functional anatomy of disorders of the basal ganglia. Trends Neurosci. 18, 63-64.

Alcantara, A. A., Chen, V., Herring, B. E., Mendenhall, J. M., and Berlanga, M. L. (2003). Localization of dopamine D2 receptors on cholinergic interneurons of the dorsal striatum and nucleus accumbens of the rat. Brain Res. 986, 22-29.

Alcantara, A. A., Mrzljak, L., Jakab, R. L., Levey, A. I., Hersch, S. M., and Goldman-Rakic, P. S. (2001). Muscarinic $\mathrm{m} 1$ and $\mathrm{m} 2$ receptor proteins in local circuit and projection neurons of the primate striatum: anatomical evidence for cholinergic modulation of glutamatergic prefronto-striatal pathways. J. Comp. Neurol. 434, 445-460.
Arbuthnott, G. W., and Wickens, J. (2007). Space, time and dopamine. Trends Neurosci. 30, 62-69.

Azam, L., Winzer-Serhan, U. H., Chen, Y., and Leslie, F. M. (2002). Expression of neuronal nicotinic acetylcholine receptor subunit mRNAs within midbrain dopamine neurons. J. Comp. Neurol. 444, 260-274.

Barbeau, A. (1962). The pathogenesis of Parkinson's disease: a new hypothesis. Can. Med. Assoc. J. 87, 802-807.

Belin, D., and Everitt, B. J. (2008). Cocaine seeking habits depend upon dopamine-dependent serial connectivity linking the ventral with the dorsal striatum. Neuron 57, 432-441.

Belin, D., Jonkman, S., Dickinson, A., Robbins, T.W., and Everitt, B. J. (2009). Parallel and interactive learning processes within the basal ganglia: relevance for the understanding of addiction. Behav. Brain Res. 199, 89-102.

Bendor, J., Lizardi-Ortiz, J.E., Westphalen, R. I., Brandstetter, M., Hemmings, H. C. Jr., Sulzer, D., Flajolet, M., and Greengard, P. (2010). AGAP1/ AP-3-dependent endocytic recycling of $\mathrm{M}(5)$ muscarinic receptors promotes dopamine release. EMBO J. 29, 2813-2826.
Bennett, B. D., and Wilson, C. J. (1999). Spontaneous activity of neostriatal cholinergic interneurons in vitro. $J$. Neurosci. 19, 5586-5596.

Bernard, V., Laribi, O., Levey, A. I., and Bloch, B. (1998). Subcellular redistribution of $\mathrm{m} 2$ muscarinic acetylcholine receptors in striatal interneurons in vivo after acute cholinergic stimulation. J. Neurosci. 18, 10207-10218.

Bernard, V., Normand, E., and Bloch, B. (1992). Phenotypical characterization of the rat striatal neurons expressing muscarinic receptor genes. J. Neurosci. 12, 3591-3600.

Berridge, K.C., and Robinson, T.E. (2003). Parsing reward. Trends Neurosci. 26, 507-513.

Bjorklund, A., and Lindvall, O. (1984). "Dopamine-containing systems in the CNS," in Handbook of Chemical Neuroanatomy, eds T. Hokfelt and A. Bjorklund (NewYork: Elsevier), 55-122.

Bolam, J. P., Hanley, J. J., Booth, P. A., and Bevan, M. D. (2000). Synaptic organisation of the basal ganglia. $J$. Anat. 196(Pt 4), 527-542.

Bonsi, P., Martella, G., Cuomo, D., Platania, P., Sciamanna, G., Bernardi, G., Wess, J., and Pisani, A. (2008). Loss of muscarinic autoreceptor function impairs long-term depression but not long-term potentiation in the striatum. J. Neurosci. 28, 6258-6263.

Brog, J. S., Salyapongse, A., Deutch, A. Y., and Zahm, D. S. (1993). The patterns of afferent innervation of the core and shell in the "accumbens" part of the rat ventral striatum: immunohistochemical detection of retrogradely transported fluoro-gold. J. Comp. Neurol. 338, 255-278.

Calabresi, P., Centonze, D., Gubellini, P., Pisani, A., and Bernardi, G. (2000). Acetylcholine-mediated modulation of striatal function. Trends Neurosci. 23, 120-126.

Calabresi, P., Centonze, D., Pisani, A., Sancesario, G., North, R. A., and Bernardi, G. (1998). Muscarinic IPSPs in rat striatal cholinergic interneurones. J. Physiol. 510(Pt 2), 421-427.

Calabresi, P., Picconi, B., Tozzi, A., and Di Filippo, M. (2007). Dopaminemediated regulation of corticostriatal synaptic plasticity. Trends Neurosci.30, 211-219.

Cartier, G. E., Yoshikami, D., Gray, W. R., Luo, S., Olivera, B. M., and McIntosh, J. M. (1996). A new alpha-conotoxin which targets alpha3beta 2 nicotinic 
acetylcholine receptors. J. Biol. Chem. 271, 7522-7528.

Centonze, D., Gubellini, P., Pisani, A., Bernardi, G., and Calabresi, P. (2003). Dopamine, acetylcholine and nitric oxide systems interact to induce corticostriatal synaptic plasticity. Rev. Neurosci. 14, 207-216.

Champtiaux, N., Gotti, C., CorderoErausquin, M., David, D. J., Przybylski, C., Lena, C., Clementi, F., Moretti, M., Rossi, F. M., Le Novere, N., McIntosh, J. M., Gardier, A. M., and Changeux, J. P. (2003). Subunit composition of functional nicotinic receptors in dopaminergic neurons investigated with knock-out mice. J. Neurosci. 23, 7820-7829.

Chergui, K., Suaud-Chagny, M. F., and Gonon, F. (1994). Nonlinear relationship between impulse flow, dopamine release and dopamine elimination in the rat brain in vivo. Neuroscience 62 , 641-645.

Contant, C., Umbriaco, D., Garcia, S., Watkins, K. C., and Descarries, L. (1996). Ultrastructural characterization of the acetylcholine innervation in adult rat neostriatum. Neuroscience 71, 937-947.

Corringer, P. J., Le Novere, N., and Changeux, J. P. (2000). Nicotinic receptors at the amino acid level. Annu. Rev. Pharmacol. Toxicol. 40, 431-458.

Cragg, S. J. (2003). Variable dopamine release probability and short-term plasticity between functional domains of the primate striatum. J. Neurosci. 23, 4378-4385.

Cragg, S. J. (2006). Meaningful silences: how dopamine listens to the ACh pause. Trends Neurosci. 29, 125-131.

Cragg, S. J., Exley, R., and Clements, M.A. (2005). "Striatal acetylcholine control of reward-related dopamine signalling," in The Basal Ganglia VIII, eds J. P. Bolam, C. A. Ingham, and P. J. Magill (New York: Springer), 99-108.

Cragg, S. J., and Rice, M. E. (2004). DAncing past the DAT at a DA synapse. Trends Neurosci. 27, 270-277.

Dajas-Bailador, F., and Wonnacott, S. (2004). Nicotinic acetylcholine receptors and the regulation of neuronal signalling. Trends Pharmacol. Sci. 25, 317-324.

De Klippel, N., Sarre, S., Ebinger, G., and Michotte, Y. (1993). Effect of M1and M2-muscarinic drugs on striatal dopamine release and metabolism: an in vivo microdialysis study comparing normal and 6-hydroxydopaminelesioned rats. Brain Res. 630, 57-64.

Descarries, L., Gisiger, V., and Steriade, M. (1997). Diffuse transmission by acetylcholine in the CNS. Prog. Neurobiol. 53, 603-625.
Descarries, L., and Mechawar, N. (2000). Ultrastructural evidence for diffuse transmission by monoamine and acetylcholine neurons of the central nervous system. Prog. Brain Res. 125, 27-47.

Descarries, L., Watkins, K. C., Garcia, S., Bosler, O., and Doucet, G. (1996). Dual character, asynaptic and synaptic, of the dopamine innervation in adult rat neostriatum: a quantitative autoradiographic and immunocytochemical analysis. J. Comp. Neurol. 375, 167-186.

Di Chiara, G., and Imperato, A. (1988). Drugs abused by humans preferentially increase synaptic dopamine concentrations in the mesolimbic system of freely moving rats. Proc. Natl. Acad. Sci. U.S.A. 85, 5274-5278.

Ding, J., Guzman, J. N., Tkatch, T., Chen, S., Goldberg, J. A., Ebert, P. J., Levitt, P., Wilson, C. J., Hamm, H. E., and Surmeier, D. J. (2006). RGS4dependent attenuation of M4 autoreceptor function in striatal cholinergic interneurons following dopamine depletion. Nat. Neurosci. 9, 832-842.

Drenan, R. M., Grady, S. R., Steele, A. D., McKinney, S., Patzlaff, N.E., McIntosh, J. M., Marks, M. J., Miwa, J. M., and Lester, H. A. (2010). Cholinergic modulation of locomotion and striatal dopamine release is mediated by alpha6alpha $4 *$ nicotinic acetylcholine receptors. J. Neurosci. 30, 9877-9889.

Everitt, B. J., and Robbins, T. W. (2005). Neural systems of reinforcement for drug addiction: from actions to habits to compulsion. Nat. Neurosci. 8, 1481-1489.

Exley, R., Clements, M. A., Hartung, H., McIntosh, J. M., and Cragg, S. J. (2008). Alpha6-containing nicotinic acetylcholine receptors dominate the nicotine control of dopamine neurotransmission in nucleus accumbens. Neuropsychopharmacology 33, 2158-2166.

Exley, R., and Cragg, S. J. (2008). Presynaptic nicotinic receptors: a dynamic and diverse cholinergic filter of striatal dopamine neurotransmission. Br. J. Pharmacol. 153(Suppl. 1), S283-S297.

Exley, R., Maubourguet, N., David, V., Eddine, R., Evrard, A., Pons, S., Marti, F., Threlfell, S., Cazala, P., McIntosh, J. M., Changeux, J. P., Maskos, U., Cragg, S. J., and Faure, P. (2011). Distinct contributions of $\alpha 4$ and $\alpha 6 \mathrm{nAChR}$ subunits in the reinforcing effects of nicotine. Proc. Natl. Acad. Sci. U.S.A. (in press).

Forster, G. L., Yeomans, J. S., Takeuchi, J., and Blaha, C. D. (2002). M5 muscarinic receptors are required for prolonged accumbal dopamine release after electrical stimulation of the pons in mice. J. Neurosci. 22, RC190.

Freund, T. F., Powell, J. F., and Smith, A.D. (1984). Tyrosine hydroxylase-immunoreactive boutons in synaptic contact with identified striatonigral neurons, with particular reference to dendritic spines. Neuroscience 13, 1189-1215.

Fuxe, K., and Agnati, L. F. (1991). Volume Transmission in the Brain. New York: Raven Press.

Garris, P. A., Ciolkowski, E. L., Pastore, P., and Wightman, R. M. (1994). Efflux of dopamine from the synaptic cleft in the nucleus accumbens of the rat brain. J. Neurosci. 14, 6084-6093.

Gerdeman, G. L., Partridge, J. G., Lupica, C. R., and Lovinger, D. M. (2003). It could be habit forming: drugs of abuse and striatal synaptic plasticity. Trends Neurosci. 26, 184-192.

Gerfen, C. R., Herkenham, M., and Thibault, J. (1987). The neostriatal mosaic: II. Patch- and matrix-directed mesostriatal dopaminergic and nondopaminergic systems. J. Neurosci. 7, 3915-3934.

Gomeza, J., Shannon, H., Kostenis, E., Felder, C., Zhang, L., Brodkin, J., Grinberg, A., Sheng, H., and Wess, J. (1999a). Pronounced pharmacologic deficits in M2 muscarinic acetylcholine receptor knockout mice. Proc. Natl. Acad. Sci. U.S.A. 96, 1692-1697.

Gomeza, J., Zhang, L., Kostenis, E. Felder, C., Bymaster, F., Brodkin, J., Shannon, H., Xia, B., Deng, C., and Wess, J. (1999b). Enhancement of D1 dopamine receptor-mediated locomotor stimulation in $\mathrm{M}(4)$ muscarinic acetylcholine receptor knockout mice. Proc. Natl. Acad. Sci. U.S.A. 96, 10483-10488.

Gonon, F. (1997). Prolonged and extrasynaptic excitatory action of dopamine mediated by $\mathrm{D} 1$ receptors in the rat striatum in vivo. J. Neurosci. 17, 5972-5978.

Gotti, C., and Clementi, F. (2004). Neuronal nicotinic receptors: from structure to pathology. Prog. Neurobiol. 74, 363-396.

Gotti, C., Clementi, F., Fornari, A., Gaimarri, A., Guiducci, S., Manfredi, I., Moretti, M., Pedrazzi, P., Pucci, L., and Zoli, M. (2009). Structural and functional diversity of native brain neuronal nicotinic receptors. Biochem. Pharmacol. 78, 703-711.

Gotti, C., Moretti, M., Clementi, F., Riganti, L., McIntosh, J. M., Collins, A. C., Marks, M. J., and Whiteaker, P. (2005). Expression of nigrostriatal alpha 6-containing nicotinic acetylcholine receptors is selectively reduced, but not eliminated, by beta 3 subunit gene deletion. Mol. Pharmacol. 67, 2007-2015.
Grace, A. A., and Bunney, B. S. (1984a). The control of firing pattern in nigral dopamine neurons: burst firing. $J$. Neurosci. 4, 2877-2890.

Grace, A. A., and Bunney, B. S. (1984b). The control of firing pattern in nigral dopamine neurons: single spike firing. J. Neurosci. 4, 2866-2876.

Grilli, M., Patti, L., Robino, F., Zappettini, S., Raiteri, M., and Marchi, M. (2008). Release-enhancing pre-synaptic muscarinic and nicotinic receptors co-exist and interact on dopaminergic nerve endings of rat nucleus accumbens. $J$. Neurochem. 105, 2205-2213.

Groves, P. M., Linder, J. C., and Young, S. J. (1994). 5-Hydroxydopaminelabeled dopaminergic axons: threedimensional reconstructions of axons, synapses and postsynaptic targets in rat neostriatum. Neuroscience 58 , 593-604.

Haber, S. N., Fudge, J. L., and McFarland, N. R. (2000). Striatonigrostriatal pathways in primates form an ascending spiral from the shell to the dorsolateral striatum. J. Neurosci. 20, 2369-2382.

Hersch, S. M., Ciliax, B. J., Gutekunst, C. A., Rees, H. D., Heilman, C. J., Yung, K. K., Bolam, J. P., Ince, E., Yi, H., and Levey, A. I. (1995). Electron microscopic analysis of D1 and D2 dopamine receptor proteins in the dorsal striatum and their synaptic relationships with motor corticostriatal afferents. J. Neurosci. 15(Pt 2), 5222-5237.

Hyland, B. I., Reynolds, J. N., Hay, J., Perk, C. G., and Miller, R. (2002). Firing modes of midbrain dopamine cells in the freely moving rat. Neuroscience $114,475-492$.

Jabourian, M., Venance, L., Bourgoin, S., Ozon, S., Perez, S., Godeheu, G., Glowinski, J., and Kemel, M. L. (2005). Functional mu opioid receptors are expressed in cholinergic interneurons of the rat dorsal striatum: territorial specificity and diurnal variation. Eur. J. Neurosci. 21, 3301-3309.

Jennings, K. A., Threlfell, S., Exley, R., and Cragg, S. J. (2009). Unmasking the role of nicotine receptors in nicotine addiction: recent advances in understanding nicotine action on dopamine systems. Cell Sci. Rev. 5, 82-112.

Jones, I. W., Bolam, J. P., and Wonnacott, S. (2001). Presynaptic localisation of the nicotinic acetylcholine receptor beta2 subunit immunoreactivity in rat nigrostriatal dopaminergic neurones. J. Comp. Neurol. 439, 235-247.

Joshua, M., Adler, A., Mitelman, R., Vaadia, E., and Bergman, H. (2008). Midbrain dopaminergic neurons and striatal cholinergic interneurons encode the difference between reward and aversive events at different epochs 
of probabilistic classical conditioning trials. J. Neurosci. 28, 11673-11684.

Kaiser, S. A., Soliakov, L., Harvey, S. C., Luetje, C. W., and Wonnacott, S. (1998). Differential inhibition by alpha-conotoxin-MII of the nicotinic stimulation of $[3 \mathrm{H}]$ dopamine release from rat striatal synaptosomes and slices. J. Neurochem. 70, 1069-1076.

Kawaguchi, Y. (1993). Physiological, morphological, and histochemical characterization of three classes of interneurons in rat neostriatum. J. Neurosci. 13, 4908-4923.

Kelley, A. E., and Domesick, V. B. (1982). The distribution of the projection from the hippocampal formation to the nucleus accumbens in the rat: an anterograde- and retrograde-horseradish peroxidase study. Neuroscience 7, 2321-2335.

Kemel, M. L., Desban, M., Glowinski, J., and Gauchy, C. (1989). Distinct presynaptic control of dopamine release in striosomal and matrix areas of the cat caudate nucleus. Proc. Natl. Acad. Sci. U.S.A. 86, 9006-9010.

Koos, T., and Tepper, J. M. (2002). Dual cholinergic control of fast-spiking interneurons in the neostriatum. $J$. Neurosci. 22, 529-535.

Kudernatsch, M., and Sutor, B. (1994). Cholinergic modulation of dopamine overflow in the rat neostriatum: a fast cyclic voltammetric study in vitro. Neurosci. Lett. 181, 107-112.

Kulak, J. M., Nguyen, T. A., Olivera, B. M., and McIntosh, J. M. (1997). Alpha-conotoxin MII blocks nicotine-stimulated dopamine release in rat striatal synaptosomes. J. Neurosci. $17,5263-5270$.

Le Novere, N., Corringer, P. J., and Changeux, J. P. (2002). The diversity of subunit composition in nAChRs: evolutionary origins, physiologic and pharmacologic consequences. J. Neurobiol. 53, 447-456.

Lehmann, J., and Langer, S. Z. (1982). Muscarinic receptors on dopamine terminals in the cat caudate nucleus: neuromodulation of $[3 \mathrm{H}]$ dopamine release in vitro by endogenous acetylcholine. Brain Res. 248, 61-69.

Lester, D. B., Miller, A. D., and Blaha, C. D. (2010). Muscarinic receptor blockade in the ventral tegmental area attenuates cocaine enhancement of laterodorsal tegmentum stimulationevoked accumbens dopamine efflux in the mouse. Synapse 64, 216-223.

Levey, A. I., Kitt, C. A., Simonds, W. F., Price, D. L., and Brann, M. R. (1991). Identification and localization of muscarinic acetylcholine receptor proteins in brain with subtype-specific antibodies. J. Neurosci. 11, 3218-3226.
Luetje, C. W. (2004). Getting past the asterisk: the subunit composition of presynaptic nicotinic receptors that modulate striatal dopamine release. Mol. Pharmacol. 65, 1333-1335.

Matamales, M., Bertran-Gonzalez, J., Salomon, L., Degos, B., Deniau, J. M., Valjent, E., Herve, D., and Girault, J.A. (2009). Striatal medium-sized spiny neurons: identification by nuclear staining and study of neuronal subpopulations in BAC transgenic mice. PLoS ONE 4, e4770. doi: 10.1371/ journal.pone.0004770

Matsuda, W., Furuta, T., Nakamura, K. C., Hioki, H., Fujiyama, F., Arai, R., and Kaneko, T. (2009). Single nigrostriatal dopaminergic neurons form widely spread and highly dense axonal arborizations in the neostriatum. J. Neurosci. 29, 444-453.

Matsumoto, M., and Hikosaka, O. (2009). Two types of dopamine neuron distinctly convey positive and negative motivational signals. Nature 459, 837-841.

McFarland, N. R., and Haber, S. N. (2000). Convergent inputs from thalamic motor nuclei and frontal cortical areas to the dorsal striatum in the primate. J. Neurosci. 20, 3798-3813.

McGeorge, A. J., and Faull, R. L. (1989). The organization of the projection from the cerebral cortex to the striatum in the rat. Neuroscience 29, 503-537.

McIntosh, J. M., Azam, L., Staheli, S., Dowell, C., Lindstrom, J. M., Kuryatov, A., Garrett, J. E., Marks, M. J., and Whiteaker, P. (2004). Analogs of alphaconotoxin MII are selective for alpha6containing nicotinic acetylcholine receptors. Mol. Pharmacol.65, 944-952.

Mirenowicz, J., and Schultz, W. (1996). Preferential activation of midbrain dopamine neurons by appetitive rather than aversive stimuli. Nature 379, 449-451.

Montague, P.R., McClure, S. M., Baldwin, P. R., Phillips, P. E., Budygin, E. A., Stuber, G. D., Kilpatrick, M. R., and Wightman, R. M. (2004). Dynamic gain control of dopamine delivery in freely moving animals. J. Neurosci. 24, 1754-1759.

Morris, G., Arkadir, D., Nevet, A., Vaadia, E., and Bergman, H. (2004). Coincident but distinct messages of midbrain dopamine and striatal tonically active neurons. Neuron 43 , 133-143.

Moss, J., and Bolam, J. P. (2008). A dopaminergic axon lattice in the striatum and its relationship with cortical and thalamic terminals. J. Neurosci. 28 , 11221-11230.

Moss, J., and Bolam, J. P. (2010). “The relationship between dopaminergic axons and glutamatergic synapses in the striatum: structural considerations," in Dopamine Handbook, eds L. L. Iversen, S. D. Iversen, S. B. Dunnett, and A. Bjorklund (Oxford: Oxford University Press), 49-59.

Nakano, K., Kayahara, T., Tsutsumi, T., and Ushiro, H. (2000). Neural circuits and functional organization of the striatum. J. Neurol.247(Suppl. 5), V1-V15.

Nirenberg, M. J., Chan, J., Vaughan, R. A., Uhl, G. R., Kuhar, M. J., and Pickel, V. M. (1997). Immunogold localization of the dopamine transporter: an ultrastructural study of the rat ventral tegmental area. J. Neurosci. 17, 4037-4044.

Nirenberg, M. J., Vaughan, R. A., Uhl, G. R., Kuhar, M. J., and Pickel, V. M. (1996). The dopamine transporter is localized to dendritic and axonal plasma membranes of nigrostriatal dopaminergic neurons. J. Neurosci. 16, 436-447.

O’Donnell, P., and Grace, A. A. (1995) Synaptic interactions among excitatory afferents to nucleus accumbens neurons: hippocampal gating of prefrontal cortical input. J. Neurosci. 15(Pt 1), 3622-3639.

Pakhotin, P., and Bracci, E. (2007). Cholinergic interneurons control the excitatory input to the striatum. $J$. Neurosci. 27, 391-400.

Partridge, J. G., Apparsundaram, S. Gerhardt, G. A., Ronesi, J., and Lovinger, D. M. (2002). Nicotinic acetylcholine receptors interact with dopamine in induction of striatal long-term depression. J. Neurosci. 22 , 2541-2549.

Pennartz, C. M., Groenewegen, H. J., and Lopes da Silva, F. H. (1994). The nucleus accumbens as a complex of functionally distinct neuronal ensembles: an integration of behavioural, electrophysiological and anatomical data. Prog. Neurobiol. 42, 719-761.

Pickel, V. M. (2000). Extrasynaptic distribution of monoamine transporters and receptors. Prog. Brain Res. 125, 267-276.

Pisani, A., Bernardi, G., Ding, J., and Surmeier, D. J. (2007). Re-emergence of striatal cholinergic interneurons in movement disorders. Trends Neurosci. 30, 545-553.

Pisani, A., Bonsi, P., Centonze, D. Gubellini, P., Bernardi, G., and Calabresi, P. (2003). Targeting striatal cholinergic interneurons in Parkinson's disease: focus on metabotropic glutamate receptors. Neuropharmacology 45, 45-56.

Quik, M., Vailati, S., Bordia, T., Kulak, J. M., Fan, H., McIntosh, J. M., Clementi, F., and Gotti, C. (2005). Subunit composition of nicotinic receptors in monkey striatum: effect of treatments with 1-methyl-4-phenyl-1,2,3,6-tetrahydropyridine or L-DOPA. Mol. Pharmacol. 67, 32-41.

Raiteri, M., Leardi, R., and Marchi, M. (1984). Heterogeneity of presynaptic muscarinic receptors regulating neurotransmitter release in the rat brain. J. Pharmacol. Exp. Ther. 228, 209-214.

Reep, R. L., Cheatwood, J. L., and Corwin, J. V. (2003). The associative striatum: organization of cortical projections to the dorsocentral striatum in rats. J. Comp. Neurol. 467, 271-292.

Rice, M. E., and Cragg, S. J. (2004). Nicotine amplifies reward-related dopamine signals in striatum. Nat. Neurosci. 7, 583-584.

Rice, M. E., and Cragg, S. J. (2008). Dopamine spillover after quantal release: rethinking dopamine transmission in the nigrostriatal pathway. Brain Res. Rev. 58, 303-313.

Salminen, O., Drapeau, J. A., McIntosh, J. M., Collins, A. C., Marks, M. J., and Grady, S. R. (2007). Pharmacology of alpha-conotoxin MII-sensitive subtypes of nicotinic acetylcholine receptors isolated by breeding of null mutant mice. Mol. Pharmacol. 71, 1563-1571.

Salminen, O., Murphy, K. L., McIntosh, J. M., Drago, J., Marks, M. J., Collins, A. C., and Grady, S. R. (2004). Subunit composition and pharmacology of two classes of striatal presynaptic nicotinic acetylcholine receptors mediating dopamine release in mice. $\mathrm{Mol}$. Pharmacol. 65, 1526-1535.

Santiago, M. P., and Potter, L. T. (2001). Biotinylated m4-toxin demonstrates more M4 muscarinic receptor protein on direct than indirect striatal projection neurons. Brain Res. 894, 12-20.

Schmitz, Y., Schmauss, C., and Sulzer, D. (2002). Altered dopamine release and uptake kinetics in mice lacking D2 receptors. J. Neurosci. 22, 8002-8009.

Schoffelmeer, A. N., Van Vliet, B. J., Wardeh, G., and Mulder, A. H. (1986). Muscarine receptor-mediated modulation of $[3 \mathrm{H}]$ dopamine and $[14 \mathrm{C}]$ acetylcholine release from rat neostriatal slices: selective antagonism by gallamine but not pirenzepine. Eur. J. Pharmacol. 128, 291-294.

Schultz, W. (1986). Responses of midbrain dopamine neurons to behavioral trigger stimuli in the monkey. $J$. Neurophysiol. 56, 1439-1461.

Schultz, W. (1998). Predictive reward signal of dopamine neurons. $J$. Neurophysiol. 80, 1-27.

Schultz, W. (2002). Getting formal with dopamine and reward. Neuron 36, 241-263. 
Schultz, W. (2006). Behavioral theories and the neurophysiology of reward. Annu. Rev. Psychol. 57, 87-115.

Sesack, S. R., Aoki, C., and Pickel, V. M. (1994). Ultrastructural localization of D2 receptor-like immunoreactivity in midbrain dopamine neurons and their striatal targets. J. Neurosci. 14, 88-106.

Sesack, S. R., Deutch, A.Y., Roth, R.H., and Bunney, B. S. (1989). Topographical organization of the efferent projections of the medial prefrontal cortex in the rat: an anterograde tract-tracing study with Phaseolus vulgaris leucoagglutinin. J. Comp. Neurol. 290, 213-242.

Shen, W., Hamilton, S. E., Nathanson, N. M., and Surmeier, D. J. (2005). Cholinergic suppression of KCNQ channel currents enhances excitability of striatal medium spiny neurons. J. Neurosci. 25, 7449-7458.

Smith, A. D., and Bolam, J. P. (1990). The neural network of the basal ganglia as revealed by the study of synaptic connections of identified neurones. Trends Neurosci. 13, 259-265.

Sugita, S., Uchimura, N., Jiang, Z. G., and North, R. A. (1991). Distinct muscarinic receptors inhibit release of gamma-aminobutyric acid and excitatory amino acids in mammalian brain. Proc. Natl. Acad. Sci. U.S.A. 88, 2608-2611.

Tayebati, S. K., Di Tullio, M. A., and Amenta, F. (2004). Age-related changes of muscarinic cholinergic receptor subtypes in the striatum of Fisher 344 rats. Exp. Gerontol. 39, 217-223.

Thomson, A. M. (2000a). Facilitation, augmentation and potentiation at central synapses. Trends Neurosci. 23, 305-312.

Thomson, A. M. (2000b). Molecular frequency filters at central synapses. Prog. Neurobiol. 62, 159-196.

Threlfell, S., Clements, M. A., Khodai, T., Pienaar, I. S., Exley, R., Wess, J., and Cragg, S. J. (2010). Striatal muscarinic receptors promote activity dependence of dopamine transmission via distinct receptor subtypes on cholinergic interneurons in ventral versus dorsal striatum. J. Neurosci. 30, 3398-3408.

Tobler, P. N., Dickinson, A., and Schultz, W. (2003). Coding of predicted reward omission by dopamine neurons in a conditioned inhibition paradigm. J. Neurosci. 23, 10402-10410.

Tzavara, E. T., Bymaster, F. P., Davis, R. J., Wade, M. R., Perry, K. W., Wess, J., McKinzie, D. L., Felder, C., and Nomikos, G. G. (2004). M4 muscarinic receptors regulate the dynamics of cholinergic and dopaminergic neurotransmission: relevance to the pathophysiology and treatment of related CNS pathologies. FASEB J. 18, 1410-1412.

Voorn, P., Vanderschuren, L. J., Groenewegen, H. J., Robbins, T. W., and Pennartz, C. M. (2004). Putting a spin on the dorsal-ventral divide of the striatum. Trends Neurosci. 27, 468-474.

Wang, Z., Kai, L., Day, M., Ronesi, J., Yin, H. H., Ding, J., Tkatch, T., Lovinger, D. M., and Surmeier, D. J. (2006). Dopaminergic control of corticostriatal long-term synaptic depression in medium spiny neurons is mediated by cholinergic interneurons. Neuron 50, 443-452.

Weiner, D. M., Levey, A. I., and Brann, M. R. (1990). Expression of muscarinic acetylcholine and dopamine receptor mRNAs in rat basal ganglia. Proc. Natl. Acad. Sci. U.S.A. 87, 7050-7054.

Wess, J., Duttaroy, A., Zhang, W., Gomeza, J., Cui, Y., Miyakawa, T., Bymaster, F. P., McKinzie, L., Felder, C. C., Lamping, K. G., Faraci, F. M., Deng, C., and Yamada, M. (2003). M1-M5 muscarinic receptor knockout mice as novel tools to study the physiological roles of the muscarinic cholinergic system. Recept. Channels 9, 279-290.

Whiteaker, P., McIntosh, J. M., Luo, S., Collins, A. C., and Marks, M. J. (2000). 125I-alpha-conotoxin MII identifies a novel nicotinic acetylcholine receptor population in mouse brain. $\mathrm{Mol}$. Pharmacol. 57, 913-925.
Wickens, J.R., Reynolds, J. N., and Hyland, B. I. (2003). Neural mechanisms of reward-related motor learning. Curr. Opin. Neurobiol. 13, 685-690.

Wilson, C. J. (2004). “Basal ganglia," in The Synaptic Organization of the Brain ed. G. M. Shepherd (Oxford: Oxford University Press), 361-414.

Wise, R. A. (2004). Dopamine, learning and motivation. Nat. Rev. Neurosci. 5, 483-494.

Wonnacott, S., Kaiser, S., Mogg, A. Soliakov, L., and Jones, I. W. (2000). Presynaptic nicotinic receptors modulating dopamine release in the rat striatum. Eur. J. Pharmacol. 393 51-58.

Woolf, N. J. (1991). Cholinergic systems in mammalian brain and spinal cord Prog. Neurobiol. 37, 475-524.

$\mathrm{Xu}$, M., Mizobe, F., Yamamoto, T., and Kato, T. (1989). Differential effects of M1- and M2-muscarinic drugs on striatal dopamine release and metabolism in freely moving rats. Brain Res. 495, 232-242.

Yan,Z., Flores-Hernandez, J., and Surmeier, D. J. (2001).Coordinated expression of muscarinic receptor messenger RNAs in striatal medium spiny neurons. Neuroscience 103, 1017-1024.

Yan, Z., and Surmeier, D. J. (1996) Muscarinic $(\mathrm{m} 2 / \mathrm{m} 4)$ receptors reduce $\mathrm{N}$ - and P-type Ca2+ currents in rat neostriatal cholinergic interneurons through a fast, membrane-delimited, G-protein pathway. J. Neurosci. 16 2592-2604.

Zhang, H., and Sulzer, D. (2004) Frequency-dependent modulation of dopamine release by nicotine. Nat Neurosci. 7, 581-582.

Zhang, W., Basile, A. S., Gomeza, J., Volpicelli, L. A., Levey, A. I., and Wess, J. (2002a). Characterization of central inhibitory muscarinic autoreceptors by the use of muscarinic acetylcholine receptor knock-out mice. J. Neurosci. 22, 1709-1717.

Zhang, W., Yamada, M., Gomeza, J., Basile, A. S., and Wess, J. (2002b). Multiple muscarinic acetylcholine receptor subtypes modulate striatal dopamine release, as studied with M1-M5 muscarinic receptor knock-out mice. $J$. Neurosci. 22, 6347-6352.

Zhou, F. M., Liang, Y., and Dani, J. A. (2001). Endogenous nicotinic cholinergic activity regulates dopamine release in the striatum. Nat. Neurosci. 4, 1224-1229.

Zhou, F. M., Wilson, C., and Dani, J. A. (2003). Muscarinic and nicotinic cholinergic mechanisms in the mesostriatal dopamine systems. Neuroscientist 9, 23-36.

Zhou, F. M., Wilson, C. J., and Dani, J. A. (2002). Cholinergic interneuron characteristics and nicotinic properties in the striatum. J. Neurobiol. 53, 590-605.

Zoli, M., Moretti, M., Zanardi, A. McIntosh, J. M., Clementi, F., and Gotti, C. (2002). Identification of the nicotinic receptor subtypes expressed on dopaminergic terminals in the rat striatum. J. Neurosci. 22, 8785-8789.

Zoli, M., Torri, C., Ferrari, R., Jansson, A., Zini, I., Fuxe, K., and Agnati, L. F. (1998). The emergence of the volume transmission concept. Brain Res. Brain Res. Rev. 26, 136-147.

Conflict of Interest Statement: The authors declare that the research was conducted in the absence of any commercial or financial relationships that could be construed as a potential conflict of interest.

Received: 30 December 2010; paper pending published: 26 January 2011; accepted: 17 February 2011; published online: 03 March 2011.

Citation: Threlfell S and Cragg SJ (2011) Dopamine signaling in dorsal versus ventral striatum: the dynamic role of cholinergic interneurons. Front. Syst. Neurosci. 5:11. doi: 10.3389/fnsys.2011.00011

Copyright (c) 2011 Threlfell and Cragg. This is an open-access article subject to an exclusive license agreement between the authors and Frontiers Media SA, which permits unrestricted use, distribution, and reproduction in any medium, provided the original authors and source are credited. 